\title{
NEW RECORDS OF LECANORA FOR BOLIVIA. II
}

\author{
Lucyna Śliwa ${ }^{1}$, Pamela Rodriguez Flakus, Karina Wilk \& Adam Flakus
}

\begin{abstract}
Members of the lichen genus Lecanora Ach. are important but still poorly known components of almost all vegetation types in Bolivia. In this paper, seven species new for Bolivia are presented: Lecanora bicincta Ramond, L. fulvastra Kremp., L. hagenii (Ach.) Ach., L. muralis (Schreb.) Rabenh., L. percrenata H. Magn., L. stramineoalbida Vain. and L. strobilina (Spreng.) Kieff. Their distributions are described and information on their diagnostic characters and chemistry is given.
\end{abstract}

Key words: biodiversity, lichenized Ascomycota, Lecanoraceae, secondary metabolites, Neotropics, South America

Lucyna Śliwa, Karina Wilk \& Adam Flakus, Laboratory of Lichenology, W. Szafer Institute of Botany, Polish Academy of Sciences, Lubicz 46, 31-512 Kraków, Poland; e-mail: l.sliwa@botany.pl

Pamela Rodriguez Flakus, Department of Botany and Molecular Evolution, Senckenberg Forschungsinstitut und Naturmuseum, Senckenberganlage 25, D-60325 Frankfurt am Main, Germany; Herbario Nacional de Bolivia, Instituto de Ecologí, Universidad Mayor de San Andrés, Calle 27, Cota Cota, Casilla 10077, La Paz, Bolivia

\section{INTRODUCTION}

A recent advanced lichenological survey in Bolivia revealed the remarkable diversity of its lichens and lichenicolous fungi, which includes a large number of newly described species (Flakus \& Kukwa 2007, 2012; Flakus 2009; Flakus et al. 2011a, 2012a; Knudsen et al. 2012; Kukwa et al. 2012a, 2013; Etayo et al. 2013a, b; Lücking et al. 2013) as well as hundreds of new national records, many of which are also new for South America (Flakus \& Wilk 2006; Flakus et al. 2008, 2011b, 2012b, 2013; Krzewicka \& Flakus 2010; Wilk 2010; Kukwa et al. 2012b; Śliwa et al. 2012a; Flakus 2013). Nevertheless, various taxonomic groups in this region are far from being fully described. Lecanoroid lichens, especially the largest genus Lecanora Ach., are the best example of this, with only 20 species recorded from the country (Rodriguez Flakus et al. 2014), in contrast with the more than 100 Lecanora species known from the Greater Sonoran Desert Region in North America (Ryan et al. 2004) or the 63 representatives of the Lecanora subfusca group exclusively reported from South and Central America (Guderley 1999).

\footnotetext{
1 Corresponding author
}

The rich collection of Lecanora we collected from diverse biogeographic regions of Bolivia over the past decade is a source of many new discoveries, some of which have been published (Śliwa et al. 2012a). Here we present the second in a series of new national records for species of the genus representing several informal groups circumscribed according to morphological, anatomical and chemical characters: the L. dispersa group, L. rupicola group, L. subfusca group and L. varia group. One species of subgenus Placodium is also included.

\section{MATERIAL AND METHODS}

Morphology and anatomy were studied by standard techniques, with preparations mounted in water or ca $25 \%$ solution of potassium hydroxide (K). Tissues were measured in water, ascospores in $\mathrm{K}$, and granulations were observed in polarized light (pol). The solubility of granules and/or crystals was tested with $\mathrm{K}$ and $65 \%$ nitric acid $(\mathrm{N})$. Lichen substances were studied by thin-layer chromatography (TLC) using the methods of Culberson and Kristinsson (1970) and Orange et al. (2001); note: the presence of chloroatranorin was not tested in this study. 
Voucher specimens are deposited in KRAM and LPB.

Abbreviations: APOLOBAMBA - Área Natural de Manejo Integrado Nacional Apolobamba; CARRASCO - Parque Nacional Carrasco; COTAPATA - Parque Nacional y Área Natural de Manejo Integrado Cotapata; SAJAMA - Parque Nacional Sajama (abbreviations of protected areas according to SERNAP Bolivia; http:// www.sernap.gob.bo).

\section{THE SPECIES}

\section{Lecanora bicincta Ramond}

Mém. Mus. Hist. Nat. 13: 248. 1825.

This species is a member of the Lecanora rupicola group, which Leuckert and Poelt (1989) studied in detail. Its phylogenetic position was clarified by Grube et al. (2004) and Blaha and Grube (2007). Lecanora bicincta is easily distinguished from other saxicolous species with pruinose apothecial discs by its apically pigmented parathecium. The dark ring that lines the outer edge of the hymenium may also occur in L. bicinctoidea Blaha \& Grube, but the latter species differs in having a thallus composed of comparatively small areoles, broadly sessile apothecia, and the development of a eucortex. Moreover, L. bicinctoidea contains an additional lichen compound methyl $3 \alpha$-hydroxy-4-O-demethylbarbatate (Blaha $\&$ Grube 2007). A similar species reported from Bolivia (Nylander 1861; Flakus et al. 2013) is L. farinacea Fée, but it lacks pigmentation of the parathecium and is also easily distinguished by the $\mathrm{C}$ - reaction of the thallus due to the absence of sordidone.

Lecanora bicincta is widespread but rare, occurring in Africa, Asia, Australasia, Europe, North America, and South America (Ryan et al. 2004) where it was recorded in Argentina (Calvelo \& Liberatore 2002). In Bolivia it was found in high mountain open vegetation.

Specimens examined. BOliVia. Dept. La Paz. Prov. Bautista Saavedra, APOLOBAMBA, near Villa Amarca village, $15^{\circ} 16^{\prime} 47^{\prime \prime} \mathrm{S}, 6^{\circ} 01^{\prime} 47^{\prime \prime} \mathrm{W}, 4643 \mathrm{~m}$, 3 July 2010, Flakus 17364 \& Rodriguez (KRAM), 17397 (KRAM, LPB); Prov. Franz Tamayo, cerca del campamento de guardaparques del APOLOBAMBA, cerro Puntani, $15^{\circ} 01^{\prime} 50^{\prime \prime} \mathrm{S}, 69^{\circ} 11^{\prime} 09^{\prime \prime} \mathrm{W}, 4770 \mathrm{~m}$, 23 April 2008, Rodriguez 545, 550 (LPB).

\section{Lecanora fulvastra Kremp.}

Fig. 1

Vidensk. Meddel. Naturhist. Foren. Kjøbenhavn 5: 17. 1874.

The species is a distinctive representative of the Lecanora subfusca group, having yellowish pruinose apothecial discs. By the presence of yellow pruina, which is rare in the genus Lecanora, the species resembles usnic acid-containing $L$. $c u$ presii Tuck. The two species differ in apothecial anatomy, with a pulicaris-type amphithecium in L. fulvastra and the absence of large crystals in the amphithecium of L. cupresii. In L. fulvastra the yellowness of the pruina is caused by the presence of calycin; it also contains atranorin, chloroatranorin and zeorin. Calycin was not detected by TLC in the Bolivian specimen, possibly due to the small amount of material used for analysis, since the collection bore only a few apothecia.

According to Lumbsch (1994), L. fulvastra is an undercollected Pantropical species. To date it has been reported only from China (Lumbsch 1994) and Central and South America: Argentina, Brazil, Columbia, the Dominican Republic and Ecuador (Guderley 1999). In Bolivia it was found in the Tucumano-Boliviano forest.

Specimen examined. BOLIVIA. Dept. Tarija. Prov. Aniceto Arce, near park guards' station, 2 hours' drive

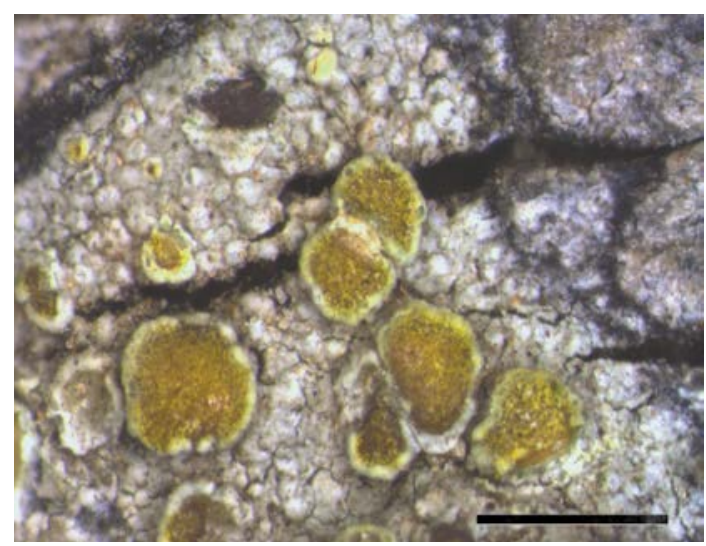

Fig. 1. Lecanora fulvastra Kremp. (Flakus 18352, LPB). Scale bar $=1 \mathrm{~mm}$. 
by car from Tarija, $22^{\circ} 14^{\prime} 56^{\prime \prime} \mathrm{S}, 64^{\circ} 32^{\prime} 55^{\prime \prime} \mathrm{W}, 883 \mathrm{~m}$, 21 Nov. 2010, Flakus 18352 (LPB).

\section{Lecanora hagenii (Ach.) Ach.}

Lichenogr. Universalis: 367. 1810.

This member of the Lecanora dispersa group seems well circumscribed on the basis of the following phenotypic characters: small apothecia with brown, usually pruinose discs; thin, white, entire to incised margins; epihymenium indistinctly granular (pol \pm , insoluble in $\mathrm{K}$, soluble in $\mathrm{N}$ ); and the lack of any lichen substances (Śliwa 2007). A similar species previously reported from the country is L. flowersiana H. Magn. (Śliwa et al. 2012a), which differs from L. hagenii in having larger, epruinose apothecia, paraphyses strongly expanded apically and coherent in $\mathrm{K}$, and longer ascospores. Detailed characteristics of $L$. hagenii and its affinities were given by Śliwa (2007) and De la Rosa et al. (2012). Despite the current circumscription of L. hagenii by Śliwa (2007), proper delimitation of the taxon is still problematic and requires resolution, as members of this morphospecies appear to be distributed across the first phylogeny of the L. dispersa group (Śliwa et al. 2012b).

The species is widespread in Europe and North America; it is also known from Asia (Śliwa 2007). In South America it was previously reported from Argentina (De la Rosa 2012). It is also on the lichen checklist of Chile (http://www.biologie.unihamburg.de/checklists/lichens-pro/south-america/ chile_1.htm). In Bolivia it occurs both in lowland Amazon forest and in high Andean open vegetation.

Specimens examined. BOliVia. Dept. Beni. Prov.

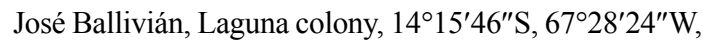
190 m, 2 Dec. 2004, Flakus 4908 (LPB). DePt. CoCHABAMBA. Prov. Quillacollo, East Cordillera, area of Inkarraya-Sipesipe, dry inter-Andean valleys, $17^{\circ} 29^{\prime} 25^{\prime \prime} \mathrm{S}$, 66 22'09"W, $3146 \mathrm{~m}, 17$ Dec. 2004, Wilk 3225 (KRAM, LPB), 3284 (KRAM). Dept. La Paz. Prov. Murillo, near Cumbre pass, $16^{\circ} 21^{\prime} 59^{\prime \prime} \mathrm{S}, 68^{\circ} 02^{\prime} 37^{\prime \prime} \mathrm{W}, 4604 \mathrm{~m}$, 13 May 2006, Flakus 5810 (KRAM).

\section{Lecanora muralis (Schreb.) Rabenh.}

Deutschl. Krypt.-Fl. 2: 42.1845.

It is the commonest and most widely distrib- uted member of the subgenus Placodium, reported from Africa, Asia, Australasia, Europe, Macaronesia, North and South America and Oceania (Ryan et al. 2004). In South America L. muralis occurs in Argentina (Calvelo \& Liberatore 2002), Chile (Pereira \& San Martin 1998) and Peru (Pavlich et al. 2005). Lecanora muralis differs from the other placodioid Lecanora known from Bolivia, L. garovaglioi (Körb.) Zahlbr., in having a much thinner, flattened thallus and lobes that are not sinuous-plicate. Lecanora muralis also lacks placodiolic acid, which was detected in addition to usnic acid and zeorin in all Bolivian samples of L. garovaglioi. For the full characteristics of the species refer to Ryan and Nash (1993), Ryan et al. (2004) and Edwards et al. (2009).

This saxicolous species was found in Bolivia in high Andean open vegetation (up to $4437 \mathrm{~m}$ ) and in the Yungas forest.

Specimens examined. BOliVia. Dept. La Paz. Prov. Bautista Saavedra, APOLOBAMBA, near Taypi Cańuma village, $15^{\circ} 03^{\prime} 20^{\prime \prime} \mathrm{S}, 69^{\circ} 09^{\prime} 07^{\prime \prime} \mathrm{W}, 4506 \mathrm{~m}$, 5 July 2010, Flakus 17530 \& Rodriguez (LPB); Prov. Franz Tamayo, cerca de la comunidad de Ulla Ulla, en el cerro Socondori Grande, $15^{\circ} 02^{\prime} 43^{\prime \prime} \mathrm{S}, 69^{\circ} 11^{\prime} 30^{\prime \prime} \mathrm{W}$, 4600 m, 3 Dec. 2007, Rodriguez 206 (LPB); Prov. Nor Yungas, COTAPATA, near Urpuma colony, $16^{\circ} 13^{\prime} 20^{\prime \prime} \mathrm{S}$, 6752'34"W, 1989 m, 30 June 2010, Flakus 17320 \& Rodriguez (KRAM, LPB). DePt. Oruro. Prov. Sajama, SAJAMA, near Sajama village, $18^{\circ} 07^{\prime} 49^{\prime \prime}$ S, 68 56'54"W, 4437 m, 18 June 2010, Flakus 16469 \& Rodriguez (KRAM), 16513 (KRAM, LPB). DEPT. Potosí. Prov. Daniel Campos, by Puerto Chuvica village near Salar Uyuni, $20^{\circ} 36^{\prime} 06^{\prime \prime} \mathrm{S}, 67^{\circ} 35^{\prime} 50^{\prime \prime} \mathrm{W}, 3670 \mathrm{~m}$, 4 Dec. 2009, Flakus 14691 \& Rodriguez (KRAM); Prov. Nor Lipez, Pinturas Rupestres near Mallku Villamar village, $21^{\circ} 46^{\prime} 20^{\prime \prime} \mathrm{S}, 67^{\circ} 29^{\prime} 05^{\prime \prime} \mathrm{W}, 4038 \mathrm{~m}, 6$ Dec. 2009 , Flakus 14778, 14781 \& Rodriguez (KRAM, LPB).

\section{Lecanora percrenata $\mathrm{H}$. Magn.}

Lichens from Central Asia I, in S. Hedin (ed.), Reports Scientific Exped. North-west. Provinces of China (the Sino-Swedish expedition). 13, XI. Botany, 1. Aktiebolaget, Thule \& Stockholm: 88. 1940.

The species is well distinguished by its white, distinctly cracked apothecial margin and dark disc, paraphyses with distinctly enlarged end cells that are coherent in $\mathrm{K}$, and narrowly ellipsoid 
ascospores. These characters make $L$. percrenata superficially resemble $L$. flowersiana but it differs from the latter by having a very dark to black apothecial disc, a brown, olive or bluish-green (not reddish) epihymenium, and usually a more prominent thallus. Lecanora percrenata also resembles the saxicolous form of L. hagenii but the latter differs in having a brownish and often pruinose apothecial disc, paraphyses that are only slightly capitate at the tips and usually free in K, and considerably shorter spores. Śliwa (2007) characterized the species in detail.

Muchnik and Śliwa (2011) gave the known world distribution of $L$. percrenata, including Asia (Afghanistan, China, Iran, Kazakhstan, Kyrgyzstan, Tajikistan), Europe (western Russia) and central and western parts of North America. The Bolivian record below extends its geographic range to South America. In Bolivia it was found in high Andean open vegetation above $4500 \mathrm{~m}$ a.s.1.

This is the first record of the species for South America.

Specimen examined. BOlivia. Dept. La Paz. Prov. Bautista Saavedra, km 162 on the road from Apolo to Charazani villages, la Cruz Charazani-Pelechuco, $15^{\circ} 15^{\prime} 00^{\prime \prime} \mathrm{S}, 6^{\circ} 02^{\prime} 51^{\prime \prime} \mathrm{W}, 4545 \mathrm{~m}, 19$ May 2011, Flakus 21169 \& Plata (KRAM, LPB).

\section{Lecanora stramineoalbida Vain.}

Figs $2 \& 3$

J. Bot. 34: 35. 1896.

Previously this characteristic Lecanora with a dark reddish-brown hypothecium was rarely reported. Morphologically the species is distinguished by its large apothecia up to $1.3 \mathrm{~mm}$ in diameter with yellowish to orange-brown discs (that may also become dark grey) and a prominent, entire, flexuose to verrucose margin. The major lichen substances detected by TLC are atranorin and 2'-O-methylperlatolic acid. As reported by Lumbsch et al. (1996), minor substances produced by the species are chloroatranorin and 2'-O-methylstenosporic acid. In this work we detected, for the first time in this lichen traces of usnic acid in addition to atranorin and 2'-O-methylperlatolic acid in the majority of the Bolivian collections. Due to the pale color of its

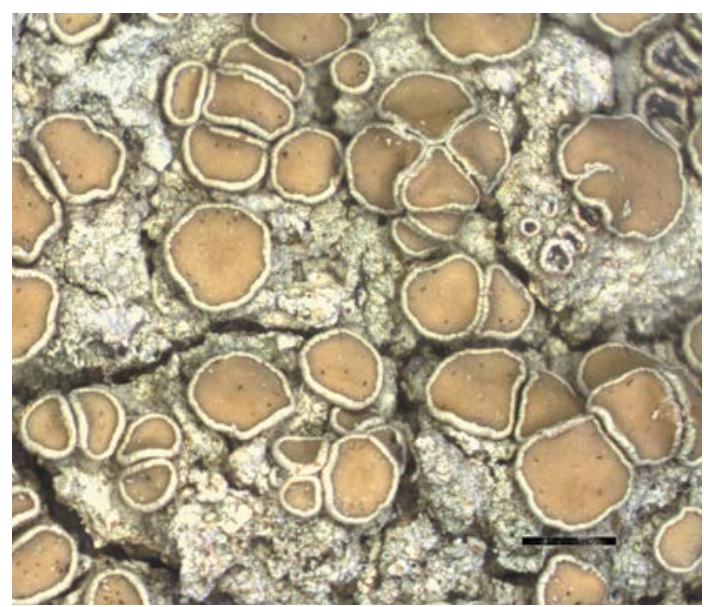

Fig. 2. Lecanora stramineoalbida Vain. (Flakus 23034, KRAM). Scale bar $=1 \mathrm{~mm}$.

apothecial discs and its chemistry, L. stramineoalbida may be confused with L. helva Stizenb, but the latter differs in having a hyaline hypothecium. Lumbsch et al. (1996) gave detailed characteristics of the species.

Lecanora stramineoalbida was previously recorded from two localities on the Antilles in Central America, Saint Vincent (locus classicus) and Guadeloupe (Lumbsch et al. 1996), and from Georgia (Sapelo Island) in North America (Lendamer \& Knudsen 2011) and Western China (Lv 2012). In Bolivia it appears to be scattered across a few departments and several provinces (Fig. 1), occurring in sub-Andean Amazon forest, the Yungas cloud forest and Tucumano-Boliviano forest as well as in savannah, at elevations between 400 and $2544 \mathrm{~m}$ a.s.1.; although known to be corticolous it was also noted on lignum and once on a rocky substrate.

This is the first record of the species for South America.

Specimens examined. BOLIVIA. Dept. Beni. Prov. José Ballivián, Yucumo village, $15^{\circ} 12^{\prime} 13^{\prime \prime} \mathrm{S}$, $67^{\circ} 01^{\prime} 50^{\prime \prime} \mathrm{W}, 400 \mathrm{~m}, 2$ Aug. 2008, Flakus 11743 \& Kukwa (KRAM, LPB), 11744 (LPB). DEPT. COCHABAMBA. Prov. Carrasco, CARRASCO, near Sehuencas village, $17^{\circ} 30^{\prime} 12^{\prime \prime} \mathrm{S}, 65^{\circ} 16^{\prime} 30^{\prime \prime} \mathrm{W}, 2220 \mathrm{~m}, 21 \mathrm{July}$ 2008, Flakus 10426 \& Kukwa, Rodriguez (LPB); Prov. Chapare, CARRASCO, near Incachaca village, 
$17^{\circ} 14^{\prime} 13^{\prime \prime} \mathrm{S}, 65^{\circ} 49^{\prime} 02^{\prime \prime} \mathrm{W}, 2294 \mathrm{~m}, 10$ June 2006, Flakus 8143 (LPB), Flakus 8150,1 \& 8157 (KRAM). DePT. LA PAZ. Prov. Abel Iturralde, near Tumupasa village, $14^{\circ} 08^{\prime} 51^{\prime \prime} \mathrm{S}, 67^{\circ} 53^{\prime} 34^{\prime \prime} \mathrm{W}, 500 \mathrm{~m}, 31$ July 2008 , Flakus 11722 \& Kukwa (KRAM, LPB), 11731 (KRAM); Prov. Franz Tamayo, between Apolo and Mapiri villages, $14^{\circ} 41^{\prime} 50^{\prime \prime} \mathrm{S}, 68^{\circ} 25^{\prime} 07^{\prime \prime} \mathrm{W}, 1490 \mathrm{~m}, 22$ Nov. 2011, Flakus 22990 (LPB); between Apolo and Mapiri villages, $13 \mathrm{~km}$ from Apolo, $14^{\circ} 50^{\prime} 51^{\prime \prime} \mathrm{S}, 68^{\circ} 21^{\prime} 38^{\prime \prime} \mathrm{W}$, 1530 m, 23 Nov. 2011, Flakus 23034, 23035.1, 23061 (KRAM, LPB); Prov. Muńecas, above Camata, NE slope, $15^{\circ} 15^{\prime} 06^{\prime \prime} \mathrm{S}, 68^{\circ} 46^{\prime} 14^{\prime \prime} \mathrm{W}, 2544 \mathrm{~m}, 15$ May 2006, Wilk $4370 b$ (KRAM); Prov. Nor Yungas, near Pacallo village, $16^{\circ} 12^{\prime} 10^{\prime \prime} \mathrm{S}, 67^{\circ} 50^{\prime} 39^{\prime \prime} \mathrm{W}, 1360 \mathrm{~m}, 3$ Aug. 2008, Flakus 11752 \& Kukwa (KRAM, LPB); Coroico village, $16^{\circ} 11^{\prime} 10^{\prime \prime} \mathrm{S}, 67^{\circ} 43^{\prime} 16^{\prime \prime} \mathrm{W}, 1550 \mathrm{~m}, 6$ June 2010 , Flakus 16394, 16397, 16408 \& Rodriguez (KRAM), $16418,16427,16444$ (LPB); COTAPATA, near Urpuma colony, $16^{\circ} 13^{\prime} 20^{\prime \prime} \mathrm{S}, 67^{\circ} 52^{\prime} 34^{\prime \prime} \mathrm{W}, 1989 \mathrm{~m}, 30$ June 2010, Flakus 17156 \& Rodriguez (KRAM), 17303 (LPB). Dept. Tarija. Prov. Aniceto Arce, Serranía de Propiedad Arnold, 22 $2^{\circ} 13^{\prime} 19^{\prime \prime} \mathrm{S}, 64^{\circ} 33^{\prime} 41^{\prime \prime} \mathrm{W}, 1309$ m, 24 Nov. 2010, Flakus 18763 (LPB); Prov. Burnet O'Connor, Lomas de la Soledad, road between Entre Ríos and Chiquiacá, $21^{\circ} 39^{\prime} 38^{\prime \prime} \mathrm{S}, 64^{\circ} 07^{\prime} 31^{\prime \prime} \mathrm{W}, 1670 \mathrm{~m}, 10$ Aug. 2012, Flakus 24174 (LPB); Papachacra, 2141'36"S,

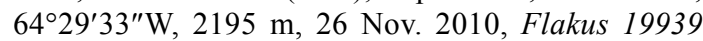
\& Quisbert (KRAM).

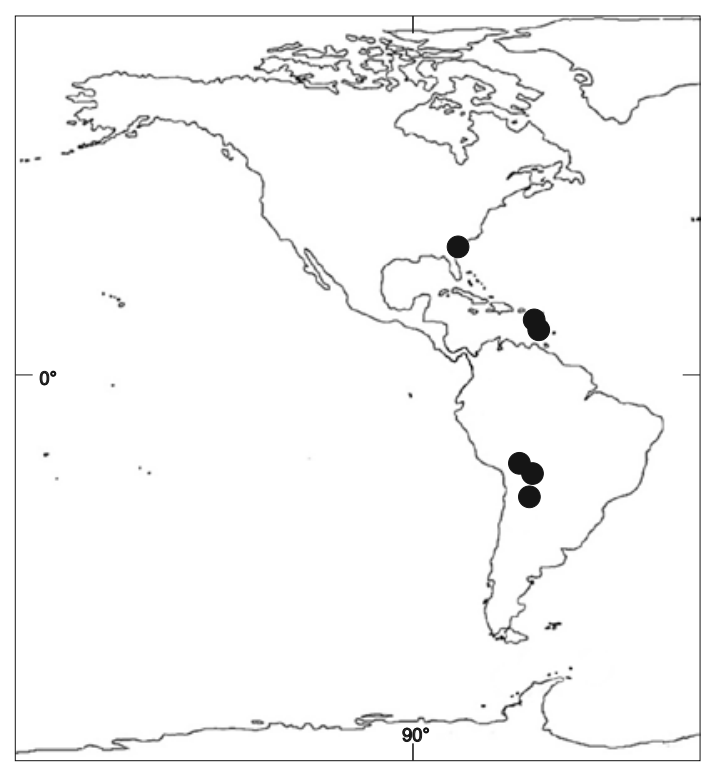

Fig. 3. American distribution of Lecanora stramineoalbida Vain.

\section{Lecanora strobilina (Spreng.) Kieff.}

Bull. Soc. Hist. Nat. Metz 19: 74. 1895.

This member of the Lecanora varia group is characterized by numerous small apothecia (up to $0.8 \mathrm{~mm}$ in diam.) with a yellowish, plane to convex disc and a thin, ecorticate thalline margin concolorous with the thallus. The presence of terpenoid crystals on the thallus and thalline margin in older specimens is also characteristic. The species is closely related to L. confusa Almb., L. perconfusa Prinzen and L. substrobilina Prinzen, from which it differs by the lack of xanthones; often these may also be absent in L. perconfusa but that species has considerably larger apothecia (up to 0.9-1.3 mm in diam.; Printzen 2001). Surprisingly, no decarboxysquamatic acid was detected in the Bolivian material of L. strobilina, although it was reported by Printzen (2001) as a characteristic constituent of it. Lecanora strobilina is also considered to be similar to L. symmicta (see LaGreca \& Lumbsch 2013); detailed descriptions of these species are also presented in Śliwa and Wetmore (2000) and Printzen (2001).

Lecanora strobilina is widely distributed in North America and also occurs in some parts of Europe and North Africa where it is rare (Printzen 2001). Pereira and San Martin (1998) reported it from South America (Chile). In Bolivia it was found in savannah and in the Tucumano-Boliviano forest at elevations above 1000-2000 m a.s.l.

Specimens examined. BOLIVIA. Dept. La Paz. Prov. Franz Tamayo, between Apolo and Mapiri villages, $14^{\circ} 41^{\prime} 50^{\prime \prime} \mathrm{S}, 68^{\circ} 25^{\prime} 07^{\prime \prime} \mathrm{W}, 1490 \mathrm{~m}, 22$ Nov. 2011, Flakus 22953,1 (LPB), 22986 (KRAM, LPB). DEPT. TARIJA. Prov. Aniceto Arce, Papachacra, 21 ${ }^{\circ} 41^{\prime} 36^{\prime \prime} \mathrm{S}$, 64²9'33"W, 2195 m, 26 Nov. 2010, Flakus 19773 \& Quisbert (LPB), 19855 (KRAM).

Acknowledgments. We are indebted to Professor Mark R. D. Seaward (Bradford) and the anonymous reviewer for critically reading the manuscript and providing important suggestions and improvements, and to Rosa I. Meneses Q. (La Paz), Director of Herbario Nacional de Bolivia, Universidad Mayor de San Andrés, for her valuable cooperation. This research received support from the Polish National Centre for Research and Development $(\mathrm{NCBiR})$ under the LIDER Programme for 
2010-2013 (no. 92/L-1/09), and from the W. Szafer Institute of Botany, Polish Academy of Sciences through its statutory funds.

\section{REFERENCES}

Blaha J. \& Grube M. 2007. The new species Lecanora bicinctoidea, its position and considerations about phenotypic evolution in the Lecanora rupicola group. Mycologia 99: 50-58.

Calvelo S. \& Liberatore S. 2002. Catálogo de los líquenes de la Argentina. Kurtziana 29: 7-170.

Culberson C. F. \& Kristinsson H. 1970. A standardized method for the identification of lichen products. J. Chromatogr. 46: 85-93.

De la Rosa I. N., Messuti M. I. \& Śliwa L. 2012. The Lecanora dispersa group (Lecanoraceae) in Argentina. Lichenologist 44: 101-114.

Edwards B., Aptroot A., Hawksworth D. L. \& James P. W. 2009. Lecanora Ach. in Luyken (1809). In: C. W. Smith, A. Aptroot, B. J. Coppins, A. Fletcher, O. L. Gilbert, P. W. JAMEs \& P. A. Wolseley (eds), The Lichens of Great Britain and Ireland: 465-502. British Lichen Society, London.

Etayo J., Flakus A. \& Kunwa M. 2013a. Capronia paranectrioides (Herpotrichiellaceae, Ascomycota), a new lichenicolous fungus from Bolivia. Lichenologist 45: 623-626.

Etayo J., Flakus A. \& Kukwa M. 2013b. Niesslia echinoides (Niessliaceae, Ascomycota), a new lichenicolous fungus on Erioderma from Bolivia. Lichenologist 45: 21-24.

Flakus A. 2009. Aspidothelium lueckingii: a new lichenized fungus from Bolivia. Nova Hedwigia 88: 139-143.

Flakus A. 2013. Foliicolous lichenised fungi of lowland Amazon forests in Pando, Bolivia. Polish Bot. J. 58: 539-554.

Flakus A. \& Kukwa M. 2007. New species and records of Lepraria (Stereocaulaceae, lichenized Ascomycota) from South America. Lichenologist 39: 463-474.

Flakus A. \& KuKwa M. 2012. New species of lichenicolous fungi from Bolivia. Lichenologist 44: 469-477.

Flakus A. \& Wilk K. 2006. Contribution to the knowledge of the lichen biota of Bolivia. J. Hattori Bot. Lab. 99: 307-318.

Flakus A., Rodriguez SaAvedra P. \& Kukwa M. 2012a. A new species, new combinations and new records of Hypotrachyna and Remototrachyna from Bolivia. Mycotaxon 119: 157-166.

Flakus A., Ahti T., Kukwa M. \& Wilk K. 2008. New and interesting records of Cladonia and their lichenicolous fungi from the Andean cloud forest in Bolivia. Ann. Bot. Fenn. 45: 448-454.
Flakus A., Elix J. A., Rodriguez P. \& Kukwa M. 2011 a. New species and records of Lepraria (Stereocaulaceae, lichenized Ascomycota) from South America. Lichenologist 43: 57-66.

Flakus A., Oset M., Jablońska A., Rodriguez SaAvedra P. \& Kukwa M. 2011b. Contribution to the knowledge of the lichen biota of Bolivia. 3. Polish Bot. J. 56: 159-183.

Flakus A., Etayo J., Schiefelbein U., Ahti T., Jablońska A., Oset M., Bach K., Rodriguez Flakus P. \& Kukwa M. 2012b. Contribution to the knowledge of the lichen biota of Bolivia. 4. Polish Bot. J. 57: 427-461.

Flakus A., Sipman H. J. M., Bach K., Rodriguez Flakus P., Knudsen K., Ahti T., Schiefelbein U., Palice Z., JablońsKa A., Oset M., Meneses Q. R. I. \& KuKwa M. 2013. Contribution to the knowledge of the lichen biota of Bolivia. 5. Polish Bot. J. 58: 697-733.

Grube M., Baloch E. \& Arup U. 2004. A phylogenetic study of the Lecanora rupicola group (Lecanoraceae, Ascomycota). Mycol. Res. 108: 506-514.

GuderLey R. 1999. Die Lecanora subfusca-Gruppe in Süd- und Mittelamerika. J. Hattori Bot. Lab. 87: 131-257.

Knudsen K., Flakus A. \& KuKwa M. 2012. A contribution to the study of Acarosporaceae in South America. Lichenologist 44: 253-262.

Krzewicka B. \& Flakus A. 2010. New records of the genus Umbilicaria (Umbilcariaceae, lichenized Ascomycota) from Bolivia. Cryptogamie, Mycologie 31: 441-451.

Kunwa M., JaVIER E. \& Flakus A. 2012a. Plectocarpon stereocaulicola (Roccellaceae, Ascomycota), a new lichenicolous fungus from Bolivia. Lichenologist 44: 479-482.

KuKwa M., Schiefelbein U. \& Flakus A. 2013. A contribution to the lichen family Graphidaceae (Ostropales, Ascomycota) of Bolivia. Herzogia 26: 231-252.

Kukwa M., Bach K., Sipman H. J. M. \& Flakus A. 2012 b. Thirty-six species of the lichen genus Parmotrema (Lecanorales, Ascomycota) new to Bolivia. Polish Bot. J. 57: 243-257.

LaGreca S. \& Lumbsch H. T. 2013. Taxonomic investigations of Lecanora strobilina and L. symmicta (Lecanoraceae, Lecanorales) in northeastern North America. Bryologist 116: $287-295$.

Lendemer J. C. \& Knudsen K. 2011. Studies in lichens and lichenicolous fungi: 7. More notes on taxa from North America. Mycotaxon 115: 45-52.

Leuckert C. \& Poelt J. 1989. Studien über die Lecanora rupicola-Gruppe in Europa (Lecanoraceae). Nova Hedwigia 49: 121-167.

Lücking R., Dal-Forno M., Lawery J. D., Bungartz F., Holgado Rojas M. E., Hernández M. J. E., MarCelli M. P., Moncada B., Morales E. A., Nelsen M. P., Paz E., Salcedo L., Spielmann A. A., Wilk K., WillWolf S. \& Yánez-Ayabaca A. 2013. Ten new species 
of lichenized Basidiomycota in the genera Dictyonema and Cora (Agaricales: Hygrophoraceae), with a key to all accepted genera and species in the Dictyonema clade. Phytotaxa 139: 1-38.

Lumbsch H. T. 1994. Calycin in Lecanora fulvastra. Lichenologist 26: 94-96.

Lumbsch H. T., Guderley R. \& Elix J. A. 1996. A revision of some species in Lecanora sensu stricto with a dark hypothecium (Lecanorales, Ascomycotina). Bryologist 99: 269-291.

Lv L. 2012. Study on the lichen genus Lecanora from Western China. Ph.D. Thesis, Shandong Polytechnic University, Jinan. http://globethesis.com/?t=1100330332491123.

Muchnik E. \& Śliwa L. 2011. New records of Lecanora percrenata, with notes on other members of $L$. dispersa group in Ryazan Region (Russia). Polish Bot. J. 56: 89-93.

NYLANDER W. 1861. Additamentum ad Lichenographiam Andium Boliviensium. Ann. Sci. Nat., Bot. 15: 365-382.

Orange A., James P. W. \& White F. J. 2001. Microchemical methods for the identification of lichens. British Lichen Society, London.

Pavlich M., LÜCKIng R. \& DíAz E. 2005. Estudio Sistemático de Líquenes de altura en la provincial de Cerro de Pasco, Junin. http://eventos.spc.org.pe/cicp2005/papers/0140/ Resumen_Liquen.pdf.

Pereira I. \& San Martin J. 1998. Flora liquénica corticícola en un bosque caducifolio de Nothofagus alessandri de Chile central. Cryptog. Bryol. Lichénol. 19: 59-72.

Printzen C. 2001. Corticolous and lignicolous species of Lecanora (Lecanoraceae, Lecanorales) with usnic and isousnic acid in the Sonoran Desert region. Bryologist 104: 382-409.
Rodriguez Flakus P., Flakus A., Kukwa M., Etayo J., Lücking R., Meneses R. I., Rivas Plata E., Stanton D., Truong C. \& VARgas R. 2014. Preliminary catalogue of lichens and lichenicolous lichens from Bolivia. Version 1.4. W. Szafer Institute of Botany, Polish Academy of Sciences, Krakow. [1 January 2014]. http://botan.botany. $\mathrm{pl} /$ lichens-bolivia.

Ryan B. D. \& NASH III T. H. 1993. Lecanora sect. Placodium (lichenized Ascomycotina) in North America. Cryptog. Bot. 3: 264-269.

Ryan B. D., Lumbsch H. T., Messuti M. I., Printzen C., Śliwa L. \& Nash III T. H. 2004. Lecanora Ach. In: T. H. Nash III, B. D. Ryan, P. Diederich, C. Gries \& F. BunGARTz (eds), Lichen Flora of the Greater Sonoran Desert Region 2: 176-286. Lichens Unlimited, Arizona State University, Tempe.

ŚliwA L. 2007. A revision of the Lecanora dispersa complex in North America. Polish Bot. J. 52: 1-70.

Śliwa L. \& Wetmore C. M. 2000. Notes on the Lecanora varia group in North America. Bryologist 103: 475-492.

Śliwa L., WilK K., Rodriguez Flakus P. \& Flakus A. 2012a. New records of Lecanora for Bolivia Mycotaxon 121: 385-392.

Śliwa L., Miądlikowska J., Redelings B. D., Molnar K. \& LuTzONI F. 2012b. Are widespread morphospecies from the Lecanora dispersa group (lichenized Lecanoromycetes, Pezizomycotina) monophyletic? Bryologist 115: 265-277.

WILK K. 2010. Icmadophila aversa and Piccolia conspersa, two lichen species new to Bolivia. Polish Bot. J. 55: 217-221.

Received 24 May 2014 